Bilingual Minds 


\section{BILINGUAL EDUCATION AND BILINGUALISM}

Series Editors: Professor Colin Baker, University of Wales, Bangor, Wales, Great Britain and Professor Nancy H. Hornberger, University of Pennsylvania, Philadelphia, USA

\section{Recent Books in the Series}

Power, Prestige and Bilingualism: International Perspectives on Elite Bilingual

Education Anne-Marie de Mejía

Identity and the English Language Learner Elaine Mellen Day

Language and Literacy Teaching for Indigenous Education: A Bilingual Approach Norbert Francis and Jon Reyhner

The Native Speaker: Myth and Reality Alan Davies

Language Socialization in Bilingual and Multilingual Societies Robert Bayley and Sandra R. Schecter (eds)

Language Rights and the Law in the United States: Finding our Voices Sandra Del Valle

Continua of Biliteracy: An Ecological Framework for Educational Policy, Research, and Practice in Multilingual Settings Nancy H. Hornberger (ed.)

Languages in America: A Pluralist View (2nd edn) Susan J. Dicker

Trilingualism in Family, School and Community Charlotte Hoffmann and Jehannes Ytsma (eds)

Multilingual Classroom Ecologies Angela Creese and Peter Martin (eds)

Negotiation of Identities in Multilingual Contexts Aneta Pavlenko and Adrian Blackledge (eds)

Beyond the Beginnings: Literacy Interventions for Upper Elementary English

Language Learners Angela Carrasquillo, Stephen B. Kucer and Ruth Abrams

Bilingualism and Language Pedagogy Janina Brutt-Griffler and Manka Varghese (eds)

Language Learning and Teacher Education: A Sociocultural Approach Margaret R. Hawkins (ed.)

The English Vernacular Divide: Postcolonial Language Politics and Practice Vaidehi Ramanathan

Bilingual Education in South America Anne-Marie de Mejía (ed.)

Teacher Collaboration and Talk in Multilingual Classrooms Angela Creese

Words and Worlds: World Languages Review Martí, P. Ortega, I. Idiazabal, A. Barreña, P. Juaristi, C. Junyent, B. Uranga and E. Amorrortu

Language and Aging in Multilingual Contexts Kees de Bot and Sinfree Makoni

Foundations of Bilingual Education and Bilingualism (4th edn) Colin Baker

For more details of these or any other of our publications, please contact: Multilingual Matters, Frankfurt Lodge, Clevedon Hall, Victoria Road, Clevedon, BS21 7HH, England http://www.multilingual-matters.com 


\section{Bilingual Minds \\ Emotional Experience, Expression and Representation}

Edited by

Aneta Pavlenko

MULTILINGUAL MATTERS LTD

Clevedon • Buffalo • Toronto 


\section{Library of Congress Cataloging in Publication Data}

Emotional Experience, Expression and Representation/Edited by Aneta Pavlenko. Bilingual Education and Bilingualism: 56

Includes bibliographical references and index.

1. Bilingualism-Psychological aspects. 2. Emotions. I. Pavlenko, Aneta. II. Series.

P115.4.E46 2006

$306.44^{\prime} 6^{\prime} 019-\mathrm{dc} 22$

2005021290

\section{British Library Cataloguing in Publication Data}

A catalogue entry for this book is available from the British Library.

ISBN 1-85359-873-9/ EAN 978-1-85359-873-9 (hbk)

ISBN 1-85359-872-0 / EAN 978-1-85359-872-2 (pbk)

\section{Multilingual Matters Ltd}

UK: Frankfurt Lodge, Clevedon Hall, Victoria Road, Clevedon BS21 7HH.

USA: UTP, 2250 Military Road, Tonawanda, NY 14150, USA.

Canada: UTP, 5201 Dufferin Street, North York, Ontario M3H 5T8, Canada.

Copyright (C) 2006 Aneta Pavlenko and the authors of individual chapters.

All rights reserved. No part of this work may be reproduced in any form or by any means without permission in writing from the publisher.

Typeset by Techset Composition Ltd.

Printed and bound in Great Britain by MPG Books Ltd. 